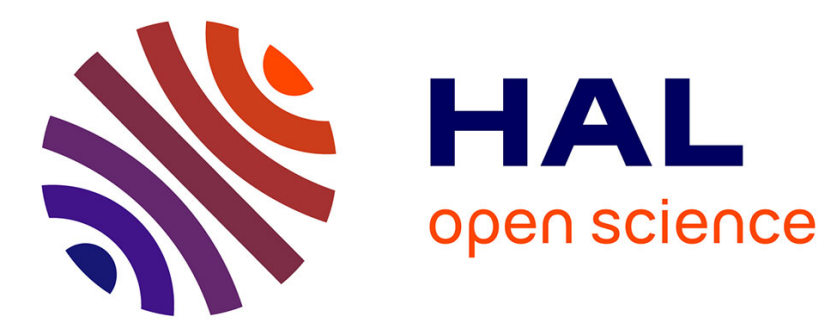

\title{
Structural phase transitions in single crystal C60
}

R. Moret, P. Albouy, V. Agafonov, R. Ceolin, D. André, A. Dworkin, H.

Szwarc, C. Fabre, A. Rassat, A. Zahab, et al.

\section{To cite this version:}

R. Moret, P. Albouy, V. Agafonov, R. Ceolin, D. André, et al.. Structural phase transitions in single crystal C60. Journal de Physique I, 1992, 2 (5), pp.511-515. 10.1051/jp1:1992161 . jpa-00246504

\section{HAL Id: jpa-00246504 https://hal.science/jpa-00246504}

Submitted on 1 Jan 1992

HAL is a multi-disciplinary open access archive for the deposit and dissemination of scientific research documents, whether they are published or not. The documents may come from teaching and research institutions in France or abroad, or from public or private research centers.
L'archive ouverte pluridisciplinaire HAL, est destinée au dépôt et à la diffusion de documents scientifiques de niveau recherche, publiés ou non, émanant des établissements d'enseignement et de recherche français ou étrangers, des laboratoires publics ou privés. 
Classification

Physics Abstracts

$61.50-64.70 \mathrm{~K}$

\title{
Short Communication
}

\section{Structural phase transitions in single crystal $\mathbf{C}_{60}$}

\author{
R. Moret $\left({ }^{1}\right)$, P.A. Albouy $\left({ }^{1}\right)$, V. Agafonov $\left({ }^{2}\right)$, R. Ceolin $\left({ }^{2}\right)$, D. André $\left({ }^{3}\right)$, A. Dworkin $\left({ }^{3}\right)$, \\ H. Szwarc $\left({ }^{3}\right)$, C. Fabre $\left({ }^{4}\right)$, A. Rassat $\left({ }^{4}\right)$, A. Zahab( $\left(^{5}\right)$ and P. Bernier $\left({ }^{5}\right)$
}

(1) Laboratoire de Physique des Solides( ${ }^{*}$ ), Bât. 510, Université Paris-Sud, 91405 Orsay, France

$\left({ }^{2}\right)$ Laboratoire de Chimie Physique, Faculté de Pharmacie, 2 bis boulevard Tonnellé, 37042 Tours, France

( $\left.{ }^{3}\right)$ Laboratoire de Chimie Physique des Matériaux Amorphes $\left({ }^{* *}\right)$, Bât. 490, Université ParisSud, 91405 Orsay, France

$\left({ }^{4}\right)$ Laboratoire d'Activation Moléculaire $\left({ }^{* * *}\right)$, Ecole Normale Supérieure; 24 rue Lhomond, 75231 Paris, France

$\left({ }^{5}\right)$ Groupe de Dynamique des Phases Condensées $\left({ }^{* * *}\right)$, Université de Montpellier, 34060 Montpellier, France

(Received 6 March 1992, accepted 11 March 1992)

Résumé . - Des cristaux de $\mathrm{C}_{60}$ ont été étudiés à basse température par diffraction des rayons $\mathrm{X}$. Nous avons mesuré l'intensité $(I)$ de réflexions caractéristiques de la transition cubique à faces centrées-cubique simple, jusqu'à $23 \mathrm{~K}$. Cette transition de mise en ordre orientationnel intervient à $T_{0}=259 \pm 1 \mathrm{~K}$ avec une hystérésis d'environ $1 \mathrm{~K}$, mais sans discontinuité de l'intensité à $T_{0}$. Des anomalies significatives de $\mathrm{d}(I) / \mathrm{d}(T)$ sont observées vers $155 \mathrm{~K}$ et $85 \mathrm{~K}$. Elles impliquent des modifications au niveau des réorientations des molécules de $\mathrm{C}_{60}$ et leur origine est analysée.

\begin{abstract}
X-ray diffraction has been employed to study the low temperature structural behavior of $\mathrm{C}_{60}$ crystals. The intensity $(I)$ of selected reflections which appear at the facecentered cubic-simple cubic transition was measured as a function of temperature down to $23 \mathrm{~K}$. This orientational ordering transition is found at $T_{0}=259 \pm 1 \mathrm{~K}$. It displays a hysteresis of about $1 \mathrm{~K}$ but no discontinuity of the intensity at $T_{0}$. Anomalies in $\mathrm{d}(I) / \mathrm{d}(T)$ around $155 \mathrm{~K}$ and $85 \mathrm{~K}$ are clearly revealed. They are associated with changes in the $\mathrm{C}_{60}$ molecular reorientations and their origin is discussed.
\end{abstract}

\footnotetext{
(*) URA 2.

(**) URA D1104.

$\left({ }^{* * *}\right)$ URA 1110.

$\left({ }^{* * * *}\right)$ URA 233 .
} 
The understanding of the orientational ordering mechanism of the $\mathrm{C}_{60}$ molecules at low temperature in pure fullerene $\mathrm{C}_{60}$ remains an important issue for this new class of molecular solids. Combining results from various types of measurements it appears that the details of the molecular reorientations and their associated dynamics are rich and still partly unravelled. At room temperature, $\mathrm{X}$-ray diffraction studies established that crystalline $\mathrm{C}_{60}$ adopts a facecentered cubic (fcc) structure where the molecules are orientationally disordered [1, 2]. This results from rapid and continuous rotations of the $\mathrm{C}_{60}$ truncated icosahedra, as shown by ${ }^{13} \mathrm{C}$ NMR [3, 4] and recent quasielastic neutron scattering measurements [5]. Differential scanning calorimetry $[2,6]$ and $\mathrm{X}$-ray powder diffraction [2] revealed a first-order transition near $250 \mathrm{~K}$ associated with a symmetry change from fcc to simple cubic (sc) at $250-260 \mathrm{~K}$.

The structure of the low temperature phase has been studied by both high resolution X-ray [2] and neutron $[7,8]$ powder diffraction methods. From these results the following picture for the orientational ordering of the $\mathrm{C}_{60}$ molecules has been proposed $[7,8]$ : below the firstorder transition at $T_{0} \approx 260 \mathrm{~K}$ the $\mathrm{C}_{60}$ molecules perform rapid rotational jumps about one or several $\langle 111\rangle$ directions (their frequency is $10-100 \mathrm{kHz}$ at $160 \mathrm{~K}[3,6,9]$ ). Two inequivalent orientations of the molecules, related by $60^{\circ}$ rotations about $\langle 111\rangle$, and corresponding to anticlockwise rotations $\phi$ of $38^{\circ}$ and $98^{\circ}$ with respect to the ideal Fm $\overline{3} \mathrm{~m}$ configuration, appear to be energetically preferred. A frequency dependent elastic anomaly in the sound velocity and attenuation at $\approx 160 \mathrm{~K}$ supports the existence of 2 such energy minima [9]. As the temperature is reduced the orientation that optimizes the electrostatic interactions $\left(\phi=98^{\circ}\right)$ is favored at the expense of that $\left(\phi=38^{\circ}\right)$ which minimizes the van der Waals contribution to the free energy. Furthermore, evidence for a possible anomaly in the cell parameter near $155 \mathrm{~K}$ has been reported. It was tentatively associated with a change from multi $<111\rangle$ rotation axes $(T>155 \mathrm{~K})$ to a single rotation axis $(T<155 \mathrm{~K})$ for each molecule. Finally, at about $90 \mathrm{~K}$, the cell parameter variation exhibits a cusp which was attributed to the freezing of the ratational degrees of freedom of the molecules.

In this paper we present the results of a $\mathrm{X}$-ray single-crystal study of the orientational ordering transition. This first-order transition is found at $T_{0}=259 \pm 1 \mathrm{~K}$ and it exhibits a hysteresis of about $1 \mathrm{~K}$. Of particular interest is the first report of anomalies in the slope of the superstructure reflection intensity $I(T)$ near $155 \mathrm{~K}$ and $85 \mathrm{~K}$.

The starting $\mathrm{C}_{60}$ material was extracted from arc-generated carbon soot with hexane-toluene mixtures and purified by column chromatography on neutral alumina. Characterization by chromatography, infrared and mass spectroscopy indicated no trace of impurity.

Single crystals, shaped as distorted octahedra, were grown by slow evaporation from toluene solutions of pure $\mathrm{C}_{60}$. Typical dimensions were of the order of $100 \mu \mathrm{m}$. Characterization by $\mathrm{X}$-ray precession photography and 4-circle diffractometry confirmed the fcc cubic symmetry with $a=14.15 \AA$. The precession photographs also reveal a pattern of diffuse lines running along $<111>$ directions and which can be attributed to close-packed stacking faults in the fcc lattice. Such faulting has been previously observed, in particular in $\mathrm{C}_{60}$ films [11].

$\mathrm{X}$-ray intensity measurements were performed using a home-built three-axis diffractometer (lifting-detector geometry) consisting of a rotating anode generator (CuK $\alpha$, fine focus, $55 \mathrm{kV}$, $20 \mathrm{~mA}$ ), a doubly-bent graphite (002) monochromator and a linear position sensitive detector (PSD). The sample was attached to the cold end of a modified Displex cryogenerator. Good thermal stability $(0.01 \mathrm{~K})$ was assured by a flow of helium gas and the temperatures were accurate to within $0.1 \mathrm{~K}$.

In a preliminary stage, oscillation photographs were made between $295 \mathrm{~K}$ and $25 \mathrm{~K}$ in order to probe extended regions of the reciprocal lattice. The fcc-forbidden superstructure reflections clearly appear on photographs taken at $250 \mathrm{~K}$ and below. Apart from the intensity buildup of these reflections as $T$ was lowered, no further modification (such as lattice distortion or new 
satellite reflections) could be found. No attempt was made to follow the lattice parameter evolution.

Some reflections were selected for intensity measurements as a function of temperature. These were performed by scanning through the peak position while integrating the intensity with the PSD. Figure 1 shows the temperature dependence of the integrated intensity (above background) of the (623) reflection between $23 \mathrm{~K}$ and $260 \mathrm{~K}$. The transition occurs at $T_{0}=$ $259 \pm 1 \mathrm{~K}$. Sweeping the temperature up and down across the transition (see the inset) reveals a hysteresis of about $1 \mathrm{~K}$ but no discontinuity of $I(T)$.

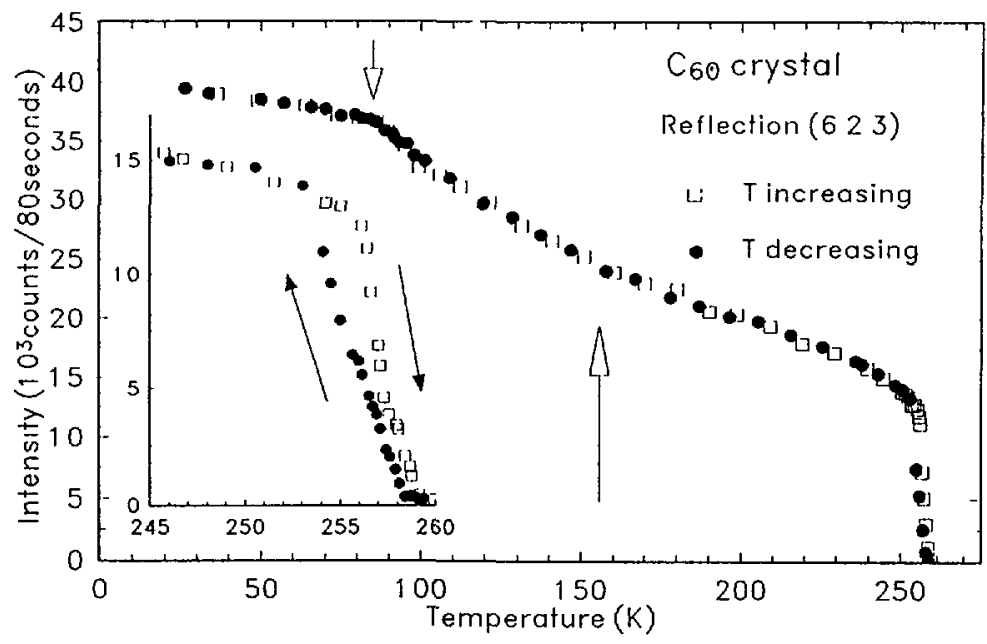

Fig. 1. - Temperature dependence of the integrated intensity of the (623) fcc forbidden reflection. Data were taken both on cooling and heating. Two anomalies are clearly visible near $155 \mathrm{~K}$ and $85 \mathrm{~K}$. An expanded view of the hysteresis below $260 \mathrm{~K}$ is displayed in inset.

Below $250 \mathrm{~K}$ the intensity still increases appreciably $(I(23 \mathrm{~K}) / I(250 \mathrm{~K}) \approx 2.4)$ in agreement with the results of Heiney et al. [2]. The temperature dependence of the intensity exhibits 2 anomalies at about $155 \mathrm{~K}$ and $85 \mathrm{~K}$. The first one is found at $T=155 \pm 10 \mathrm{~K}$ with an inflexion of $I(T)$ (change of curvature, $\mathrm{d}^{2} I / \mathrm{d} T^{2}$ becomes positive below $155 \mathrm{~K}$ ) and a sudden increase of $-\mathrm{d} I / \mathrm{d} T$. A second anomaly in the intensity was observed at $T=85 \pm 5 \mathrm{~K}$, with a break in the rate of increase of the intensity $(-\mathrm{d} I / \mathrm{d} T$ smaller below $85 \mathrm{~K}$ ). The two anomalies are reproducible both on cooling and heating the sample (see Fig. 1) and a very similar behavior of $I(T)$ was obtained for the (612) reflection.

These results shed light on some aspects of the orientational ordering in solid $\mathrm{C}_{60}$, as discussed now. Beginning with the first-order transition at $T_{0}$ it is worth noting that the value of $T_{0}$ appears to depend on the particular sample. For instance the transition was found at $254 \pm 1 \mathrm{~K}$ for a second crystal from a different batch. Previous studies have shown that the characteristics of the transition depend on the cristallinity $[4,10]$ of the sample and also on its purity, as solvated crystals exhibit a lower transition temperature [9]. Another factor to consider is the existence of close-packed stacking faults in the fcc crystals. These defects are probably intrinsic to the growth mechanism of these van der Waals solids [11] and their concentration may vary, even for crystals taken from the same preparation. Their influence on the 
molecular ordering remains to be quantitatively evaluated.

The first order nature of the transition is clearly demonstrated by the small hysteresis at $T_{0}$. Its magnitude $(\delta T \approx 1 \mathrm{~K})$ compares well with that obtained by differential thermal analysis $(\delta T \approx 1 \mathrm{~K})[12]$ but it is smaller than that reported from sound velocity measurements $(\delta T \approx 2.5 \mathrm{~K})[9]$. The same factors which were invoked for $T_{0}$ (cristallinity, purity, stacking faults) can probably account for the variability of $\delta T$ as well. The fact that we observe no discontinuity of $I(T)$ can be understood if the two phases coexist in the crystal and this may again be influenced by the nature and concentration of defects.

It is very likely that the anomaly observed at $T=155 \mathrm{~K}$ bears the same origin as the weak change of slope in the cell parameter previously detected by high resolution neutron measurements at the same temperature [8]. A quantitative change in the dynamics of the molecular reorientations cannot account for these effects. An interesting suggestion by David et al. [8] is that above $155 \mathrm{~K}$ each molecule rotates about different $\langle 111\rangle$ directions, while it rotates about a single $\langle 111\rangle$ axis below $155 \mathrm{~K}$. In both temperature ranges long-range intermolecular correlations must preserve the cubic symmetry. However it is not clear to us at the moment that this would cause a larger rate of increase of $I(T)$ below $155 \mathrm{~K}$. On the other hand David et al. also find that the relative proportion of the $\phi=98^{\circ}$ configuration of the $\mathrm{C}_{60}$ molecule increases as the temperature decreases. Although this behavior was found to be initiated as high as $260 \mathrm{~K}$, it would be tempting to associate $155 \mathrm{~K}$ with the temperature at which the stabilization of the $\phi=98^{\circ}$ configuration becomes sizeable. According to this model the progressive removal of the orientational disorder between the $\phi=38^{\circ}$ and $\phi=98^{\circ}$ configurations would be responsible for the faster increase of the intensity below $155 \mathrm{~K}$.

The lower anomaly at $85 \pm 5 \mathrm{~K}$ leads to a reduced temperature dependence of the intensity at low temperature and it is probably related to the cusp in the lattice parameter reported by David et al. [8] at about $90 \mathrm{~K}$. The authors suggested that this effect corresponds to the freezing of the molecular rotations, which hinders a complete stabilization of the $\phi=98^{\circ}$ configuration over the $\phi=38^{\circ}$ one, thus leading to some residual static disorder. The break in $I(T)$ (Fig. 1) with a smaller $(-\mathrm{d} I / \mathrm{d} T)$ at low temperature may be attributed to the saturation of an order parameter below $85 \mathrm{~K}$ and thus appear to confirm this model. Actually, the behavior of $I(T)$ is similar to that found in a number of materials such as the organic conductor (TMTSF) ${ }_{2} \mathrm{ClO}_{4}$ (TMTSF is the molecule of tetramethyltetraselenafulvalene) where the orientational ordering of the $\mathrm{ClO}_{4}^{-}$tetrahedra at $24 \mathrm{~K}$ can be quenched under moderately rapid cooling rates, leading to a saturation of the superstructure reflection intensity [13]. It would be interesting to investigate possible cooling rate effects in the present case and for instance it may be feasible to achieve a better orientational ordering of the $\mathrm{C}_{60}$ molecules under slower cooling rates.

The most significant result of our single crystal X-ray diffraction study is that two well defined anomalies in the temperature dependence of the intensity of fcc forbidden reflections were found at about $155 \mathrm{~K}$ and $85 \mathrm{~K}$, below the first-order orientational ordering transition at $259 \mathrm{~K}$. These results compare well with a recent neutron diffraction study by David et al. [8]. While the $85 \mathrm{~K}$ anomaly is likely to be due to the freezing of the molecular reorientations, the origin of the $155 \mathrm{~K}$ effect is still uncertain. Model calculations and fits to the $I(T)$ curve should help to clarify this interesting issue.

\section{Acknowledgements.}

We appreciate helpful discussions with S. Ravy and J.-P. Pouget and thank W.I.F. David et al. for communicating their results prior to publication. 


\section{References}

[1] Fleming R.M., Siegrist T., Marsh P.M., Hessen B., Kortan A.R., Murphy D.W., Haddon R.C., Tycko R., Dabbagh G., Mujsce A.M., Kaplan M.L. and Zahurak S.M., Mat. Res. Soc. Symp. Proc. (Materials Research Society, Pittsburgh) 206 (1991).

[2] Heiney P.A., Fisher J.A., McGhie A.R., Romanow W.J., Denenstein A.M., McCauley Jr J.P., SMiTh III A.B. and Cox D.E., Phys. Rev. Lett. 66 (1991) 2911.

[3] Yannoni C.S., Johnson R.D., MeiJer G., Bethune D.S. and Salem J.R., J. Phys. Chem. 95 (1991) 9.

[4] Tycko R., Dabbagh G., Fleming R.M., Haddon R.C., Makhija A.V. and Zahurak S.M., Phys. Rev. Lett. 67 (1991) 1886.

[5] Neumann D.A., Copley J.R.D., Cappelletti R.L., Kamitakahara W.A., Lindstrom R.M., Creegan K.M., CoX D.M., Romanow W.J., Coustel N., McCauley Jr J.P., MALISZEwSKYJ N.C., Fisher J.E. and SMiTH III A.B., Phys, Rev. Lett. 67 (1991) 3808.

[6] Dworkin A., Szwarc H., Leach S., Hare J.P., Dennis T.J.S., Kroto H.W., Taylor R. and Walton D.R.M., C.R. Hebd. Acad. Sci. Paris Série II 312 (1991) 979.

[7] David W.I.F., Ibberson R.M., Matthewman J.C., Prassides K., Dennis T.J.S., Hare J.P., Kroto H.W., TAYlor R. and Walton D.R.M., Nature 353 (1991) 147.

[8] David W.I.F., IbBerson R.M., DENNIS T.J.S., HARE J.P. and Prassides K., Europhys. Lett. in press.

[9] Shi X.D., Kortan A.R., Williams J.M., Kini A.M., Savall B.M. and Chaikin P.M., Phys. Rev. Lett. 68 (1992) 827.

[10] Dworkin A., Fabre C., Schutz D., Kriza G., Ceolin R., Szwarc h., Bernier P., Jérome D., Leach S., Rassat A., Hare J.P., Dennis T.J., Kroto H.W., Taylor R. and Walton D.R.M., C. R. Hebd. Acad. Sci. Paris Série II 313 (1991) 1017.

[11] Luzzi D.E., Fisher J.E., WANG X.Q., RicketTs-Foot D.A., MCGHIE A.R. and RoMaNow W.J., J. Mater. Res. (1992) to be published.

[12] Kriza G., Ameline J.-C., Jérome D., Dworkin A., Szwarc H., Fabre C., Schutz D., RAsSat A., Bernier P. and Zahab A., J. Phys. I France 1 (1991) 1361.

[13] Moret R., Pouget J.-P., Comes R. and BechgaArd K., J. Phys. France 46 (1985) 1521. 